charcoal of our ancestors have been displaced by the with nitric acid. The difference in the energy of the ordinary slow-burning powder and of the smokeles
powder now used can be seen by consulting any table where the two are conpared. One which I recently examined showed that guns, otherwise practically three times the weight of ordinary powder to get the We must not forget, while discussing ordnance, the remarkable development of what are known as "quickfiring guns." This, as you know, is really the adap breech mechanism used on the modern small arms,
and it has been carried so far that modern quick-firing guns are now made of as large caliber as eight inches giving a wuzzle energy of over 10,000 foot-tons, while the number of tines the gun can be discharged in breech-loader. In the stnaller sizes of these quick-
firing guns the rapidity of fire is almost incredible and I remember being particularly struck by the re from a six-pounder to have five projectiles in the air

More than a quarter of a century ago what are now known as machine guns were introduced $:$ that is dinary small arms and slightly larger were so arranged that the ammunition could be fed almost continuously
and the rapidity of fire be so great that a single weapon would be equal to a conpany of soldiers. A you are doubtless aware, the Gatling gun was th earliest of these. These. too, have been develope
during the intervening years, until it would seem that
finality has almost been reached in the Maxim gun where when once started it continues to discharge
itself by the effect of its own recoil, until the old metaphor "iron rain and leaden hail" becones a simper minute from a caliber of 0.45 inch or less.
We come now to the machinery of the modern ves sel, and I trust that you will pardon me if I go int greater detail here, because this is my own special
feld and one where it has been my lot to have been fleet. Here, more than almost any where else in the war vessel, the constant demand has been for greate power on less weight, and at the same time the de-
mand has also been for thoroughly reliable machinery Progres also be economical.

Progress has been so rapid that it sometimes seem perfect as possible and see it thoroughly tested in render what appeared so perfect relatively obsolete.
Shortly before I became Engineer-in-Chief of th Navy, forced draught had been reintroduced, after
many years of disuse, which at once gave an enormous many years of disuse, which at once gave an enormous increase of boiler power with a very slight increase
of weight, due to the burning of a much larger amount
of coal on a given grate surface. The shell boiler was developed until its design semed nearly perfect, but
we were confronted with the problem of getting plate sufficiently thick to withstand the increasing steam
pressures in the large boilers and still be able to pro perly work the plates in our shops. The weight of
these boilers was always very great for the power developed, and in the large sizes which they had reached the utmost skill was necessary for their proper care when further progress with the shell boiler seemed in-
possible, the water-tube boiler was developed to such possible, the water-tube boiler was developed to such a point that it gave us the necessary solution of the itself into a determination of the best form of wate tube boiler, inasmuch as we are now sure that we can
construet boilers which will withstand any pressure that are likely to be used and which are satisfactory
in every other respect. These boilers offer almost abin every other respect. These boilers offer almost a
solute safety against disastrous explosion, afford great reduction in weight, and are built to withstan cerned, thus giving freedom from such troubles as leaky tubes and leaky seams, to which large she The demand for reduction of weights in the engine has been met by the use of stronger materials, and
also their disposition in shapes where a given weight of material offers the greatest resistance. hollow forgings of oil-tempered steel, and the uses of tions. Besides the greater strength of the materials,
just as important an item is their much greater relia test pieces will be absolutely true of every part of the whole rnass. gines which run at much greater speeds than formerly
obtained. Thisseems a sufficiently simple matter, and yet it was not possible until the improvement came in
materials, combined with an accurate scientific knowledge of sowe of the questions confronting the marine rnle of thumb. This is notably the case with propoint that really held down the engine speeds. Inasmuch as the whole office of the motive machinery is to necessary to design the propeller first and nake everyhave accurate scientific knowledge of the conditions governing propeller design, we know that the propeller sirable for the engines, and this enables us to choose
engine speeds which will give us both lighter and more econonical ones than were possible in olden days.
A problem in the design of engines for war vess
which is of considerable difficulty, and the solution which is not yet thoroughly satisfactory, is that of with the capacity for the power necessary at maximun speeds. As you are doubtless aware, the power neces.
sary to drive a vessel varies approximatelv as the cube sary to drive a vessel varies approximatelv as the cube
of the speed, so that if, as is ordinarily the case, the cruising speed is about half the maximum, the power
to be developed is one-eighth or less of the maximum. As was very cleverly expressed by one of ny forneras
sistants (Prof. Hollis) some years ago, the problem is like that of having a beast of burden whose maximum is so adjustable that he could be economically used for work which could be perforined by a donkey. You actly true of a steam engine, it nevertheless is true
that its economy when worked at powers which are
such a small percentage of the naximum is very much reduced. In some of our ships we have tried to solve that at the moderate powers the forward set can be ment whereby the large cylinders of her triple expansion engines could be disconnected, leaving the engines to run as smaller compounds at cruising speeds. A ville," where the large cylinder of a quadruple expansion engine can be thrown out, leaving a triple expan-
sion for lower powers. The objection to all of these is full power, it is often inposibible to stop to couple up This was exemplified in a marked way in the case of the "Brooklyn" during the fight at Santiago. She to stop to couple up, which would have necessitated fo stop to couple up, which would have necessitate another solution, which was used on the "Columbia" system, if properly carried out, would be entirely satisscrew only for ordinary cruising, and a ship, as you
doubtless know, is not so handy with one serew as with two. Our latest design to meet the desire to use two screws and still get relatively small engines for cruising speeds is to use three screws but make the leaving each of the wing screws to develop only a any vessels on this plan, so that while theoretically we not as yet been tried in practice.

A very interesting illustration of the application of ingenuity and scientific knowledge is the method tion of the hull. As engine speeds and hull dinensions increased, there came a conbination of circum-
stances, causing excessive vibration of the hull, due to
unbalanced inertia stresses of the reciprocating of the engines. The solution is a very simple adaptawith a special arrangement of crank angles and weights of reciprocating parts. The adoption of the
steam turbine has also been suggested to accomplish steam turbine has also been suggested to accomplish some torpedo boats. With certain very promising tages, and before the steam turbine becomes a for mous amount of skill and ingenuity uust be exercised,
and the lines along which they can act are not yet a.p parent. mum results tax the judginent and experience of the designer, as well as his skill and ingenuity. If time permitted, it would be of the greatest interest to show items has given us special classes of vessels. 'Thus in mobility or speed has been sacrificed, while in the duced to secure high speed. In the torpedo boat fieed to it. The tendency just now seems to be along the line of having only one class of armored vessels vessel of about 12,000 to 14,000 tons displacement, with 8 to 10 inches of Krupp arnor. a battery of 10 -inch rapid-fire guns, and a speed of about 20 to 21 knots.
We have now given a hasty glance at the principal elements of the modern war vessel, although I regret the consideration of many features which could not
have failed to be of interest to you, such as the workshops on board where the necessary routine repair
are made to keep the great machine in working order the electric installation for lighting the various por-
tions of the ship and providing the searchlights; the tions of the ship and providing the searchlights; the and the torpedoes, with their wonderfully intricat work automatically after being discharged from the control at every moment. I trust, however, that you will have heard enough to satisfy you that the theme The truth is that in

The skill, ingenuity, and scientifee, due to the exercise of the modern war vessel has thoroughly kept pace. A moment's reflection would, of course, make it ver vessels such as we now possess unless there had been a corresponding development in every other manufacSecretary of the Navy, touched upon a very important was known as the "Personnel Bill." It it comparin the development of naval science to the point where
it became necessary for every officer in the navy to be an engineer, so that it is necessary for the modern
admiral to know many things of which our great Farwould, of course, require vastly greater skill to handle the complicated mechanism which the modern war
vessel is than one of the old ones, but that, just, as we handle the less complicated vessels of former times, so without doubt we would get competent men to bandl those of to-day. He had learned the fact that the
modern warship is a vast engine, and to be properly controlled must be handled by engineers. Congress as soon as we can nake the necessary arrangements,
every officer in the navy charged with the handling of a vessel shall be a trained engineer, and, therefore, we the organisms of the nuachine becone, we shall have to properly care for the valuable and delicate maI have had a part in two wars, in both of which the navy played an important part and became dear to the people, and I have also passed through the inter
vening interval, during much of whish the navy seem the late war showed we not. only know how to build good ships but to make them go and to fight them,
our fellow citizens in civil life will see to it that the navy is maintained in a state of the highest efficiency, both as to personnel and material, ever ready for effi-
cient use when needed. In this work, which on both interest, and I trust that, just as your influence has for seventy-fve years been on the side of the gcueral ad vancement of engineering in the weechanic arts, so it
will be on the side of their advancement in the navy.

THE CHARGING AND CARE OF UTOMOBILE BATTERIES By Theodore D. Bunce.

IT is certainly not necessary that the owner of an with every detail of the construction of his vehicle. both mechanical and electrical, any more than we
would expect every driver of a horse to be a veterinarian. But if every owner were as conversant with the perienced driver is in the care and handling of his horse
this article would be uncalled for. It is probable that the majority of automobile owners will not care to
study the scientific construction of the batteries that study the scientific construction of the batteries that
furnish the power for their machines, but they will furnish the power for their machines, but they will
wish to have a practical knowledge of their working. be compared with the horse. Both nay be overwork-
ed with more or less disastrous results. The battery
nay, like its equine rival, be over as well as under fed, the latter condition in both being worse than the former. Both are the better off when not subjected to sudpushed to their utmost capacity: Both renew their
strength and usefulness after a reasonable rest, and last, but not least, both require when ill the care of an tery the skilled electrician.

The motor, while forming an important part of the mechanism, is more a part of the vehicle proper than
the battery, and receives attention with the general to discuss the construction or care of the motor, but to vital part of the mechanism. The general features of driver in order to obtain the best service and to econo-
mize the power.
The storage battery of an autonobile usually consists
of 40 to 44 cells, generally divided into four groups of 10 or 11 cells each. Each cell gives from $21 / 2$ volts when
fully charged to 1.75 volts each when it has arrived a the lowest potential it should be allowed to reach on discharge. This gives a maximum of from 100 to 110
volts and a minimum of from 70 to 77 . As the majority of direct current circuits that would be used for charg why 40 cells is the best number to use, as the 110 -vol why 40 cells is the best number to use, as the 110-volt
circuit will always give the necessary excess of pressure
required to force the current through the cells, at the required to force the current through the cells, at the
same time requiring the least amount of resistance for regulating.
In the majority of automobiles the change of speed is eff ected by grouping the cells in sets. It is for this reason that a wultiple of four is used for the total num.
ber. Thus $44 \div 4=11$, or $40 \div 4=10$. The mechan-
isu for operating takes care of this grouping. It will be found on removing the cells from the vehicle that
each set of 10 or 11 cells are pernanently connected in series-that is, the positive of one cell to the negative
of the next, and so on. In the vehicle each set is conleading to the controller.

In charging, all the sets should be connected in serie that is, the four groups connected together, the posigenerally provided for by the manufacturer of the vewires and setting the controller at full speed. This is
It is generally accomplished by disconnecting the moto obvious, as all the cells are used in series when the full power is to be developed. It is important, however, to remember to disconnect the motor wires before turning
the controller to full speed. If it is desired to charge the cells independently of the vehicle, or an individua and connected in series, leaving they may be removed terminal and a negative at the other. The positive pole is generally indicated either by a + sign or by a
red mark. The negative pole is sonetimes indicated by a -- sign, but it is more frequently unmarked. properly marked by the manufacturer, and the indiproperly marked by the manufacturer, and the indiThe electrolyte or fluid used in the cells is a mixture of sulphuric acid and water. The strength of this solution varies with the state of charge of the battery.
When the cells are fully charged the solution is at its maxinum strength, and becones weaker in proportion not require replacing except when the cells are to be
diswantled for cleaning or repairs. There should always be sufficient in the cells to cover the tops of the plates, as any portion left exposed is inactive and will by evaporation or spilling, but this may be replaced
by the addition of clean water. But should any con- 
siderable amount be required, it is better to add acid, in order not to weaken the electrolytes. The plugs in necessary water added to replace evaporation. A spe.
cial rubber bulb with a gmall nozzle is made for this purpose. of $22^{\circ}$ by Bauns hydrometer, or a specific gravity of
$1 \cdot 180$. Preparing with a hydrometer is better than mixing by measure or weight, as the density of the pure acid may vary. With the comnercial acid th proportions by measure are 1 part sulphuric acid and
5 parts water. The solution should be made in a stone vessel or lead-lined tank. Put a sufficient quantity of
water in the vessel and slowly pour in the acid, stirring
it constantly with a glass rod or a piece of wood. The solution gets hot and becomes stronger as it cools Test it with the hydrometer, and if it is of about 20
let it stand until cold, when either acid or water may let it stand until cold, when either acid or water may not Iet the acid come in contact with any metal but lead: The pure acid is exceedingly corrosive, and the

$A_{B}$ it is impossible to use the hydrometer in the batteries made for automobile work, it will be necessary to withdraw some of the acid with a suction bulb or syringe, and a test made in a separate vessel. A con
venient instrument is made for this purpose, called venient instrument is made for this purpose, called a
hydrometer syringe. It is a combination of a suction hydrometer syringe. It is a combination of a suction
bulb and a tube holding the hydrometer. As long as the cells are working uniformly it is not necessary to found of a low voltage, the acid will be correspondin ly weak, and it may be difficult to make it recover it original strength by charging. If fresh solution is put in it should be diluted after the cell has been restored ing the plates.

The charging wires should be run to a convenien switch board und should be connected to an ammeter. The rheostat should be of large enough capacity to carry the maximum charging rate without overheating and should have a sufficient number of steps for the mined and the poles properly marked. If there is any possibility of the polarity being changed, a test with a
polarity indicator should be made each time before polarity indicator should be made each time befor

In most cases the celis will be charged in the wagon and the directions given by the manufacturer should wagon should beattached to a cable of convenient length and the ends connected to the terminals on the switch board. The polarity at the plug should then be tested and made to correspond with the marks on it. It is rheostat is set with all the resistance in circuit and the current turned on. If plenty of time can be allowed in which to charge, the normal rate should be adhered to but if it is necessary to hurry the charging, the maxi-
mum tnay be applied at first and then reduced as the cells begin to show signs of being charged.

As soon as the bubles rise to the surface of the acid freely or the sound of bubbling can be plainly heard bling continues, and if at the lowest point it still conevident the cells are nearly charged. It is advisable to continue charging at a low rate, as ther an opportunity to catch up, while an over-charge at a low rate will not injure the others.

If a battery has been over-discharged it will be necessary to conthue the charge for a longer time, as even up to its full capacity: In the latter case the battery should be taken out of the vehicle and the plugs re moved froin the cells, so that each cell can be inspected. The gas much ventilation should be given as possible, and great care should be taken to have no fire allowed near. The cells should be examined by an incandescent lamp. charge. A heavy over-discharge even a prolonged charge will not always bring the cells back to their origina condition, but if the following discharges are moderate always advisable to charge the battery as soon as possible after it has been used, and if convenient give it a short charge shortly before taking out the vehicle. When an autornobile is used every day, two sets of
batteries will be found of advantage, as there will be more opportunity to give them attention and a longer are recorninended, as a fault ouce developed in a cell paired at once. paired at once. the care of automobile batteries. Much more could be said of a technical nature. Other currents than the 110-volt circuit may be used for ch arging, but with the increase in the number of vehicles and charging facili-
ties they will rarely be called upon. ties they will rarely be called upon. called positive and negative. Each group has attache to it a connecting strip of lead. The plates alternate in the jar. so that one plate is of opposite sign to the of insulation that allow of a free circulation of the solution. When the charging current passes in at one pole chemical change in the nature of the plates. When ed and when the circuit is closed a regction takes place and a chemical change of an opposite character occurs. This produces an electric curre
tricity is actually stored. - Horseless Age.

At Marquette, Michigan, a 35-foot lifeboat has been equipped with a 12 horse power engine in an air-tight
channber. The engine was kept steadily running during the test, which involved the rolling over and over fere with the self-righting ability of the boat, which made 7 miles per hour when on an even keel.

\section{LIQUID AIR}

LIQUEFACTION OF GASES.

By Prof. T. o'conor sloane.

365 pages. 800 . Containing many illustrations, woith portraits
of Faradoy, Pictet, Cailletet, Dewar and Tripler. Price \$2.50.

In offering this book to be public, the publishers feel th th as it is the
onty urork on the subject, they are beiping in forwarding the bigher scien

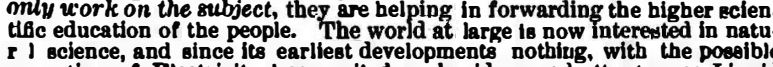
exception of Electricity, bas exciled such widespread attention as Liquid

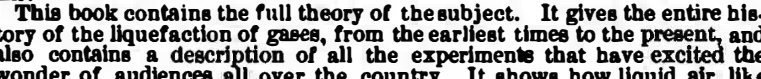

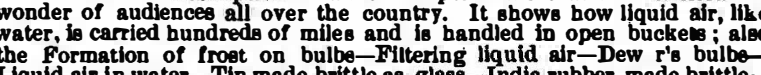

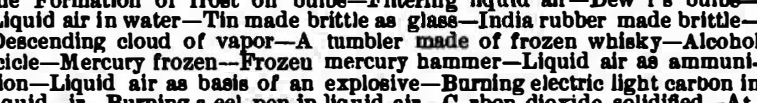

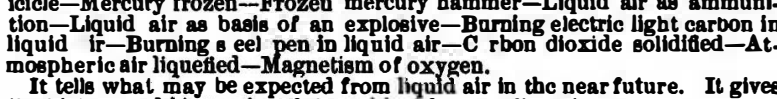

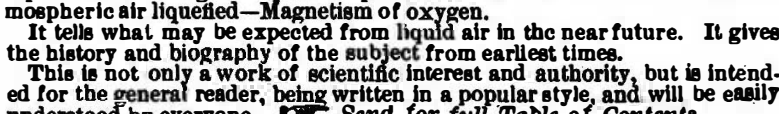

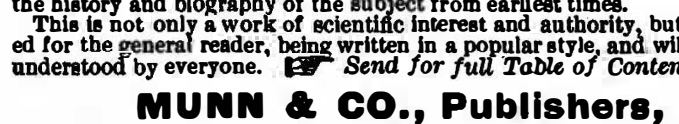
361 Broadway, Now York.

\section{EXPERIMENTAL SCIENCE.} BY GEO. M. HOPKINS.

Twentieth Edition, Revised and Rnlarged. 914 Pages. 820 Mustrations. Elegantly bound in Cloth. Price, by mail,

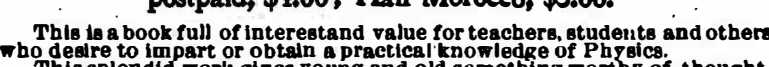

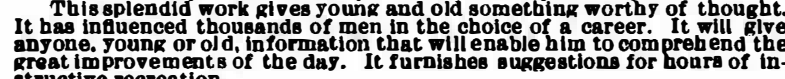
What the Press says of "Experimental Sclence." "Mr. Thopking has rendered a valu.
able Bervice to experimental physics."
Even hino Post.

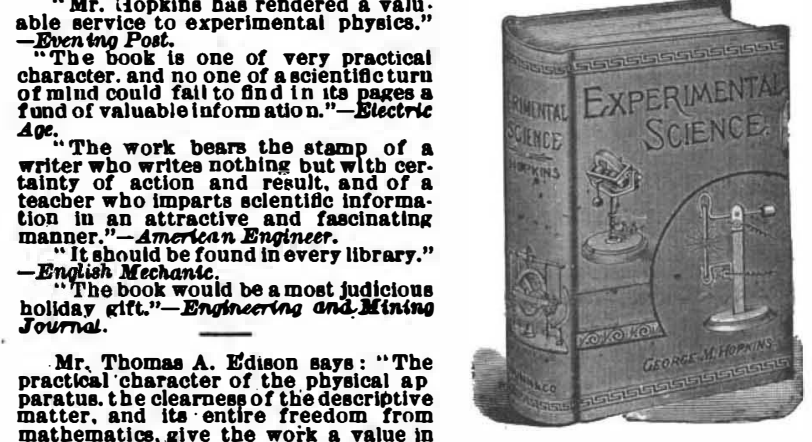

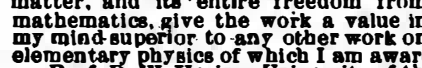

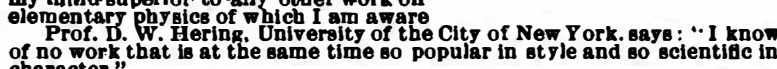

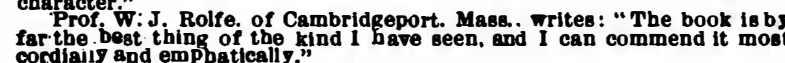
Hundreds of cordial recommendations from eminent Professors
and Scientlic men.

Send for Illustrated Circular and Table of Contents.

THE SCIENTIFIC AMERICAN

CYCLOPEDIA of RECEIPTS, NOTES and QUERIES EOITED BY ALBERT A. HOPKINS.

12,500 Recelpts, 708 Pages.

Price, $\$ 5$ in cloth; $\$ 6$ in sheep; $\$ 6.50$ in half monoceo; Postpaid
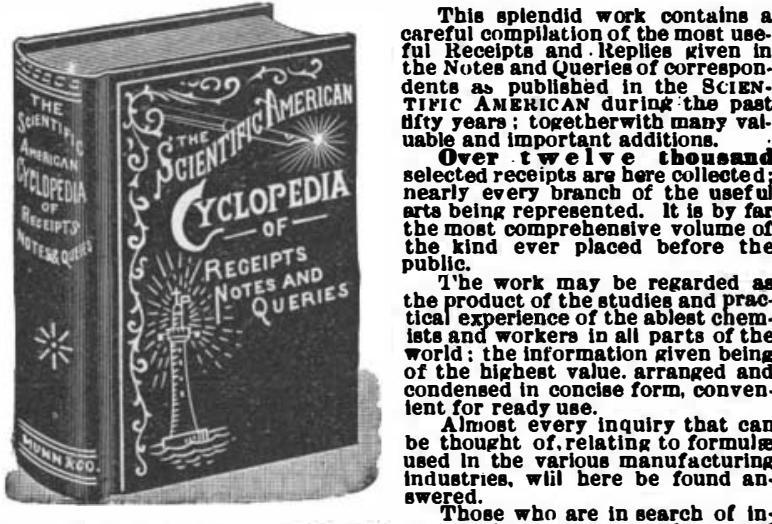

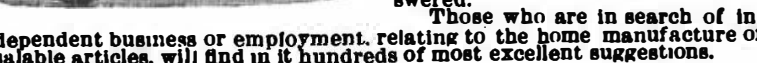

\section{ElECTRICAL LiBRARY}

By Prof. T. O'CONOR sLoANe.

Comprising five books, as follows:

A rith metic of Elee triclty, 138 pages.................81.00 How to Become a 8nccean pal Electriclan, 18 . pp. 1.0 Btandard Electrical Dictionary, 682 pages........... 3.00

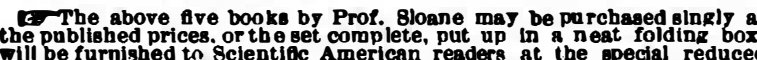

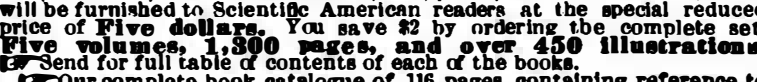

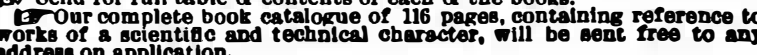
IIUNI \& CO., Publishers, 361 Broadway, W. Y.
$\boldsymbol{P}=\boldsymbol{M}$

\section{Scientific American Supplement.}

PUBLISHED WEEKLY.

Terms ot Subscription, $\mathbf{8 5}$ a Year.

Bent by mail, postage prepaid. to subscribers in ang
part of the United States or Canacia. Bix dollars a part of the United States or Canada. Bix dollars a
year. sent prepaid, to any forejgn country. Ali the back numbers of TrE SUPPLEMENT, from the commencement. January 1, 1876, can be had. Price,
com the

10 cents eaci. wise be suppiied. Two volumes are i sued yearly.
Price of each volum $8, \$ 2.50$ stitched in paper, or 83.50 bound in stiff covers

COMBINED RATES.-One copy of SCIENTIFIC AMERICAN and one copy of SCIENTTIFIC AMERICAN SUPPLH A liberal discount to booksellers, news agents, and canvassers.

MUNN \& CO., Publishere, agl Broadway, New York.

TABLE OF CON'TENTS.

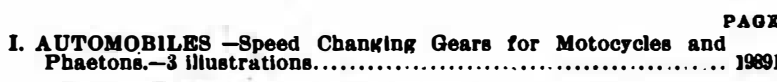
II. BIOGR APH Y Ÿ.-Robert Wilheim Bunsen.-1 illustration........... 19896 1II. COMARRCE-Commerclal Africa IV. ELECTRICITY:-The Charging and Care of Automobile Bat. 1980 V. GROLOGY.-The Wrecking of Krakatoa.............................. 1989 VI. ILLUMINANT8 - Acetylene for Lantern and Enlarging .......... 1980 VII. MARINE ARCHITECTURE. - Boats and Salli- -Tools for VIII. METEOKOLOGY.-Hurricane in Guadeloupe. ................... 1989

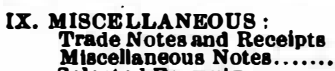

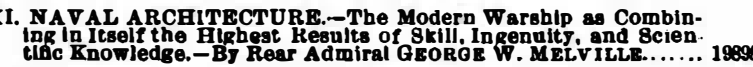

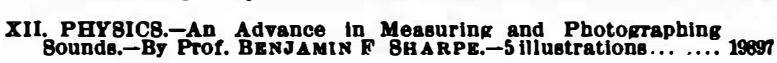
XIII. 8CULPTURE.-The Dewey Arch.-5 Illustrations:............... 1989

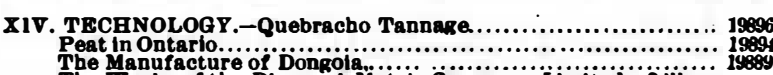

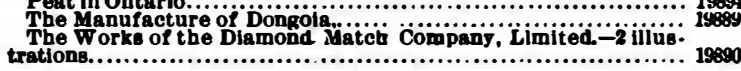
XV TRA TRE AND EXPLORATION.-8cenes in Totí.-2 Illustra.

\section{Automobiles}

The Scientific American for May 13, 1899, is devoted mainly to illustrations and detailed de scriptions of various types of horseless vehicles. of the bicycle and detailed drawings of an automo bile tricycle. Price 10 cents.
The following copies of the ScIENTIFIC AMERTCAN SUPPLEMENT give many details of Automo biles of different types, with many illustrations of the vehicles, motors, boilers, etc. The series mak bers are : 732, 979, 993, 1053, 1054, 1055, 1056, 1057, 1058 , 1059, 1075, 1078, 1080. 1082, 1083, 1099, 1100 , MENT No. 1229 contains a highlo interesting article giving full data as to operating costs of horse and 10 cents each, by mail. For sale by all newsdeal. MUNN \& Co., Publishers,

361 Broadway, - - - New York City.

\section{BUILDING EDITION}

SCIENTIFIC AMERICAN.

Those who contemplate building should not fail to ONLY 82.60 A YEAR.

Semi-annual bound volumes $\$ 2.00$ each, yearly bound volumes $\$ 3.50$ each, prepaic by nuail. pariets of country houses; also a handsolue COLORED PLATE.

SINGLE COPIES - - - - 25 CENTS EACH. MUNN \& CO., 361 Broadway, Now York

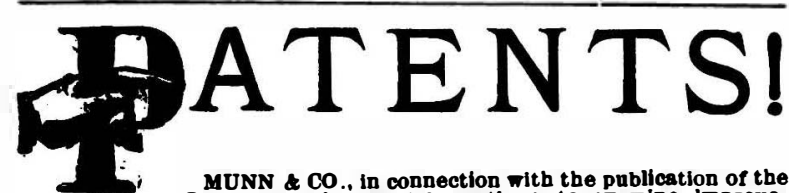

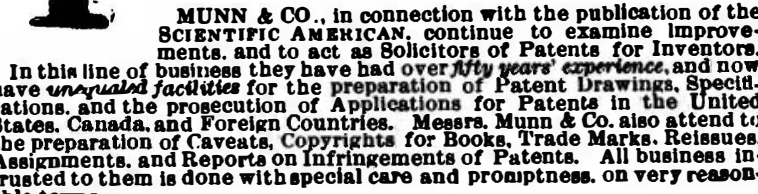

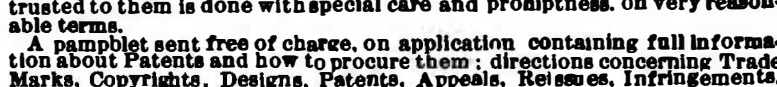
Marks, Copprights, Desicns. Patents. Apoeds. Ke the cost and method torld.

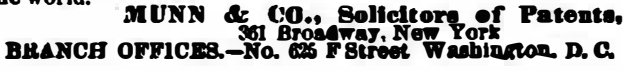

